\title{
STUDY OF BODY MASS INDEX (BMI), BODY FAT PERCENT (\%BF), AND WAIST TO HIP RATIO (WHR) IN MALE PHYSICAL EDUCATION STUDENTS \\ Mehrzad Shabani $^{1}$, Saeid Shakerian ${ }^{1}$, Rouholah Fatemi ${ }^{2}$ \\ ${ }^{1}$ Ahvaz Shahid Chamran University, Ahvaz, Iran. \\ ${ }^{2}$ Ahvaz Jundishapur University of Medical Sciences, Ahvaz, Iran.
}

\begin{abstract}
The purpose of this study was to investigate body mass index (BMI), body fat percent (\%BF) and waist-hip ratio (WHR) of physical education male students of Shahid Chamran University and comparison with national and international body composition standards. Material: Subjects were seventy five male students physical education male students of Shahid Chamran University of mean age (23.21 \pm 2.78$)$, mean height (174 \pm 5.71$)$ and mean weight (70.07 \pm 9.43$)$ who were selected randomly. Some of body composition indices were determined with body composition analyzer apparatus (bioelectrical impedance apparatus). Results: Descriptive characteristics of subjects include: body fat percent (19.37 \pm 3.62$)$, waist-hip ratio $(0.80 \pm 0.037)$ and body mass index (23.18 \pm 2.68$)$. To categorize and regulate data we used descriptive analyzes, to calculate Pearson correlation coefficient we used presumption analyzes and to compare the obtained data with national standards we used $\mathrm{T}$-test statistical procedure. There are significant correlations between body mass index and waist-hip ratio $(\mathrm{P}=0.709, \mathrm{r}=0.001)$, between body mass index and body fat percent $(\mathrm{P}=0.783, \mathrm{r}=0.001)$ and between body fat percent and waist-hip ratio $(\mathrm{P}=0.809, \mathrm{r}=0.001)$. There are significant differences between mean body mass index and its national standard $(\mathrm{P}=0.001)$, between mean waist-hip ratio and its national standard $(\mathrm{P}=0.001)$ and between mean body fat percentage and its national standard $(\mathrm{P}=0.001)$. Conclusions: Results revealed that according to national standards of body fat percentage and body mass index of subjects, they were assigned to more than intermediate limitation; it may be due to abnormal nutrition, unregulated exercise or physical activity and heredity.
\end{abstract}

Key words: Body composition, body fat percentage (\%BF), body mass index (BMI), waist-hip ratio (WHR)

\section{Introduction}

Overweight and obesity are major, and increasing, public health concerns in all parts of the globe. Obesity increases the risk of chronic health consequences including hypertension, hypercholesteroaemia, hyperglycaemia, type II diabetes and cardiovascular diseases. In Australia, 19\% of adult males and 22\% of adult females are considered obese and the direct health care costs of obesity are estimated at approximately $\$ 830$ million annually (Thorburn et al. 2005). To relate obesity directly to health risks, assessment of both total body fat deposition and distribution as subcutaneous or visceral fat are important. Methods frequently used to determine overall body fatness include Body Mass Index (BMI; body mass $(\mathrm{kg}) /$ stature $\left.(\mathrm{m})^{2}\right)$ and percentage body fat $(\% \mathrm{BF})$. However, a number of studies have shown that it is not appropriate to use a single BMI cut-off point to detect obesity as different BMI-\%BF relationships have been observed in different ethnic groups (Deurenberg-Yap M et al. 2000; Deurenberg P et al. 2003). Using anthropometry, a previous study found that the BMI value of $23 \mathrm{~kg} / \mathrm{m} 2$ for young Japanese adults equates with a BMI value of $25 \mathrm{~kg} / \mathrm{m} 2$ for Australian Caucasians (Kagawa et al. 2006).

The use of BMI in this way has a number of limitations, including its inability to distinguish between fat mass and non-fat mass (Norgan \& Ferro-Luzzi, 1982; Garn et al. 1986; Ross et al. 1988). These limitations may become an important issue when comparing ethnic groups with distinctively different body proportions or physiques. Several studies have suggested that the relationship between BMI and \%BF (i.e. the BMI-\%BF relationship) varies with age, gender and ethnicity (Schaefer et al. 1998; Deurenberg et al. 2002; Chang et al. 2003).

Longitudinal study which it performed in Hardward University during 27 years on 19292 students with mean age 46.6 years old had been shown that rate of mortality in men who had body mass index (BMI), $26 \mathrm{~kg} / \mathrm{m} 2,1.67$ times is more than men who had body mass index, $22,5 \mathrm{~kg} / \mathrm{m}^{2}$ (Altan O. et al. 1999). Body mass index in male students of Thrtoww University is reported as $22.8 \mathrm{~kg} / \mathrm{m}^{2}$ (Jurimae.T et al. 1991), but by Clasey et al in Virginia University, it is reported as $24.7 \mathrm{~kg} / \mathrm{m}^{2}$ (Clasey. Jl. et al. 1999).

In this study, we investigated BMI, percent body fat, and waist - hip ratio in male students of physical education and sport sciences field and we compared them with Iran national and international standards.

\section{Methodology}

The study was approved by the Human Research Ethics Committees of Shahid Chamran University of Ahwaz. In this study, we measured body mass index (BMI), percent body fat (\%BF), and waist to hip ratio (WHR) by using Bioelectrical Impedance apparatus

\section{Subjects}

Statistical population included 162 students of physical education and sport sciences field of Shahid Chamran University Ahwaz Iran and we selected simple randomly 75 students from statistical population.

(C) Mehrzad Shabani, Saeid Shakerian, Rouholah Fatemi, 2015

http://dx.doi.org/10.15561/20755279.2015.0309 


\section{Measurements}

Test performed at $8 \mathrm{AM}$ and subjects were fasting and they had not done any body activity before test. Test had been done through using Bioelectrical Impedance apparatus producted by GWON Corporation Korea, model Olympia.

Statistical analysis

To demonstrate means and standard deviation of study variables (BMI, \%BF, and WHR) we used quantify statistical procedures and to determine relationships between measured variables - Pearson correlation coefficient; to determine difference between measured variables and Iran national and international standards we used independent $\mathrm{T}$ test. Statistical analysis was done by using SPSS software version 17.

\section{Results}

In this research, students had height, $174 \pm 5.71 \mathrm{Cm}$ and weight, $23.18 \pm 2.68$. Total subjects' data are given in table 1, means and standard deviations of study variables (BMI, \%BF, and WHR) are shown in table 2, percentage of BMI, BF, and WHR according to Iran national norm exhibit in table 3, percentage of BF, and WHR and percentage of BMI according to international standard are respectively given in table 4 and table 5, comparison between variables in this research (BMI, \%BF, and WHR) with Iran national standard are presented in table 6, and relationships between study variables - in table 7. In this study, significant level was 0.05 .

Table1.

Total subjects data

\begin{tabular}{|c|c|c|c|}
\hline variable & $\begin{array}{c}\text { Mean and standard } \\
\text { deviation }\end{array}$ & Minimum & 26 \\
\hline Age & $23.21 \pm 2.78$ & 18 & 193 \\
\hline Height & $174 \pm 2.78$ & 54.10 & 102.7 \\
\hline Weight & $70.07 \pm 9.43$ & & 165 \\
\hline
\end{tabular}

Table2.

\begin{tabular}{|c|c|c|c|}
\hline \multicolumn{3}{|c|}{ Means and standard deviations of study variables $(B M I, \% B F$, and $W H R$ Maximum } \\
\hline variable & $\begin{array}{c}\text { Mean and standard } \\
\text { deviation }\end{array}$ & 11.80 & 32.90 \\
\hline BMI & $19.37 \pm 2.78$ & 18.30 & 33.90 \\
\hline WHR & $23.18 \pm 5.71$ & 0.70 & 0.94 \\
\hline
\end{tabular}

Percentage of BMI, BF, and WHR according to Iran national standard

\begin{tabular}{|c|c|c|c|c|c|c|c|c|c|c|c|c|c|c|}
\hline \multirow[t]{2}{*}{ variable } & \multicolumn{2}{|c|}{ Very low } & \multicolumn{2}{|c|}{ Low } & \multicolumn{2}{|c|}{$\begin{array}{c}\text { Moderate } \\
\text { low }\end{array}$} & \multicolumn{2}{|c|}{ Moderate } & \multicolumn{2}{|c|}{$\begin{array}{l}\text { Moderate to } \\
\text { high }\end{array}$} & \multicolumn{2}{|c|}{ High } & \multicolumn{2}{|c|}{ Very high } \\
\hline & No & $\%$ & No & $\%$ & No & $\%$ & No & $\%$ & No & $\%$ & No & $\%$ & No & $\%$ \\
\hline$\% \mathrm{BF}$ & 0 & 0 & 0 & 0 & 2 & 3 & 10 & 13 & 18 & 24 & 32 & 43 & 13 & 17 \\
\hline BMI & 1 & 1 & 10 & 13 & 6 & 8 & 15 & 20 & 16 & 22 & 15 & 20 & 12 & 16 \\
\hline WHR & 14 & 18 & 16 & 21 & 16 & 21 & 22 & 28 & 5 & 7 & 2 & 5 & 1 & 1 \\
\hline
\end{tabular}

According to table 3, body fat percentage of most subjects in three age classifications assigned to in moderate to high and high classifications, body mass index of most subjects in three age groups assigned to in moderate, moderate to high and high classifications and waist-hip ratio of most subjects in three age classifications assigned to in moderate classification. 
Table4.

Percentage of BF and WHR according to International national standard

\begin{tabular}{|c|c|c|c|c|c|c|c|c|c|c|}
\hline \multirow{2}{*}{ Variable } & \multicolumn{2}{|c|}{ Low } & \multicolumn{2}{c|}{ Excellent } & \multicolumn{2}{c|}{ Good } & \multicolumn{2}{c|}{ Moderate } & \multicolumn{2}{c|}{ Bad } \\
\cline { 2 - 11 } & No & $\%$ & No & $\%$ & No & $\%$ & No & $\%$ & No & $\%$ \\
\hline WHF & 0 & 0 & 4 & 5 & 25 & 34 & 29 & 39 & 17 & 22 \\
\hline
\end{tabular}

In table 4 we can see that percentage of body fat of most subjects assigned to moderate and good classifications and waist - hip ratio of most subjects in three age groups assigned to excellent classification.

Table5.

Percentage of BMI according to International national standard

\begin{tabular}{|c|c|c|c|c|c|c|c|c|}
\hline \multirow{2}{*}{ Variable } & \multicolumn{2}{|c|}{ Thin } & \multicolumn{2}{c|}{ Normal } & \multicolumn{2}{c|}{ Overweight } & \multicolumn{2}{c|}{ Fat } \\
\cline { 2 - 8 } & No & $\%$ & No & $\%$ & No & $\%$ & No & $\%$ \\
\hline BMI & 0 & 0 & 60 & 80 & 12 & 16 & 2 & 3 \\
\hline
\end{tabular}

Table 5 exhibits that body mass index of most subjects in three age groups are assigned to normal classification.

Comparison between variables in this research (BMI, \%BF, and WHR) with Iran national norm

\begin{tabular}{|c|c|c|}
\hline & $\mathrm{t}$ & Significant levels \\
\hline Variable & 2.531 & $0.013^{*}$ \\
\hline BMI & 9.724 & $0.001^{\circledR}$ \\
\hline WHR & -6.301 & $0.001^{\circledR}$ \\
\hline
\end{tabular}

$*: \mathrm{P}<0.05, \AA: \mathrm{P}<0.01$.

In table 6 we present comparison between variables in this research (BMI, \%BF, and WHR) with Iran national standard. Obtained results from this table show that there are significant differences between subjects BMI, \%BF, and WHR with theirs Iran national standard (respectively $\mathrm{P}<0.013, \mathrm{P}<0.001$, and $\mathrm{P}<0.001$ ).

Table7.

Relationships between study variables

\begin{tabular}{|c|c|c|c|}
\hline Variable & BMI & $\% \mathrm{BF}$ & WHR \\
\hline BMI & 1 & $\mathrm{r}=0.783$ & $\mathrm{r}=0.709$ \\
& $\mathrm{P}=0.001^{\circledR}$ & $0.01^{\circledR}$ \\
\hline \%BF & $\mathrm{r}=0.783$ & $\mathrm{r}=0.809$ \\
& $\mathrm{P}=0.001^{\circledR}$ & 1 & $\mathrm{P}=0.001^{\circledR}$ \\
\hline WHR & $\mathrm{r}=0.709$ & $\mathrm{r}=0.809$ & 1 \\
\hline
\end{tabular}

(): $\mathrm{P}<0.01$.

Table 7 shows that there are relationships between $\mathrm{BMI}$ and $\% \mathrm{BF}(\mathrm{r}=0.783, \mathrm{P}=0.001)$, between $\mathrm{BMI}$ and WHR $(\mathrm{r}=0.709, \mathrm{P}=0.001)$, and between WHR and \%BF $(\mathrm{r}=0.809, \mathrm{P}=0.001)$.

\section{Discussion}

In the study it is reported that body mass index of male untrained athletics from Thrtoww university of Estonia was $22.8 \mathrm{~kg} / \mathrm{m}^{2}$ (Jurimae. T et al, 1991). Clasey. Jl. et al reported that body mass index of male trained students from Virginia University was $24.7 \mathrm{~kg} / \mathrm{m}^{2}$ (Clasey. Jl et al, 1999). Observed difference in results of this study can occur due to various economic, social, and cultural conditions which there are in different universities. Having compared results of this research with World Health Organization (WHO) standard, we determined that \%79 male students of physical education filed of Shahid Chamran University of Ahwaz have optimal weights and they are healthy and can be assigned to minimum danger rate.

Mean body mass index of students, comparing with its national standard shows that they can be assigned to classification "moderate to high". Probable reason of current result can increase percentage of body fat. Also mean BMI of male physical education students of Shahid Chamran University of Ahwaz, compared with its national standard, shows that there is significant difference between their mean BMI (Masaharu Kagawa et al, 2007). 
Waist - hip ratio in this study is in significant correlation with body mass index $(\mathrm{r}=0.709, \mathrm{P}=0.001)$. Current result is in accordance with Altan O. et al research's results that it likelihood was due to accumulating body fat in waist and hips (Altan O. et al, 1999).

Ninety four percent of male physical education students of Shahid Chamran University of Ahwaz located excellent WHR range, that is why they were put into minimum danger rate and they had low abdomen fat (Bray G.A., 1985).

In this research it is shown that there is positive significant correlation between percentage of body fat and waist hip ratio $(\mathrm{r}=0.809, \mathrm{P}=0.001)$. In general, body composition of students in this study, in comparison with Iran national standard, in better situation in respect to health. Body mass index of subjects was higher than Iran national standard that may be due to increased weight of subjects and can be as resulted from intake of additional kilo calories from food materials and also it possibly could be caused by irregular daily activities (Ronald K et al, 2006).

In general, in this research we determined suitable correlation between percentage of body fat, waist - hip ratio, and body mass index in subjects that could be caused by low daily activity and increased kilo calories intake through elevated food consumption, which can result in increasing of body fat in waist and hips and also can result in increased body mass index (Masaharu Kagawa et al, 2007).

\section{Acknowledgment}

This study was supported by Sport Physiology Department, Shahid Chamran University, Ahwaz, Iran. We submitted this article to my friends and we thank them.

\section{References:}

Altan O, Vedat S, Omer u. Waist circumference and waist to hip ratio in Turkish adults: interrelation with other risk factors and association with cardiovascular disease. International journal of cardiology 1999;70(1):43-50.

Bray GA Complications of obesity. Annals of internal medicine 1985;103:10-52.

Chang C-J, Wu C-H, Chang C-S, Yao W-J, Yang Y-C, Wu J-S \& Lu F-H. Low body mass index but high percent body fat in Taiwanese subjects: implications of obesity cutoffs. Int J Obes Relat Metab Disord 2003;27:253-259.

Clasey Jl, Kanaley JA. Validity of methods of body composition assessment in young and older men and women. J. Appl physio, 1999;86(5):1728-1738.

Deurenberg P, Bhaskaran K, Lian PL. Singaporean Chinese adolescents have more subcutaneous adipose tissue than Dutch Caucasians of the same age and body mass index. Asia Pacific J Clin Nutr 2003;12:261-265.

Deurenberg P, Deurenberg-Yap M \& Guricci S. Asians are different from Caucasians and from each other in their body mass index/body fat per cent relationship. Obes Rev 2002;3:141-146.

Deurenberg-Yap M, Schmidt G, van Staveren WA, Deurenberg P. The paradox of low body mass index and high body fat percentage among Chinese, Malays and Indians in Singapore. Int J Obes 2000;24:1011-1017.

Garn SM, Leonard WR \& Hawthorne VM Three limitations of the body mass index. Am J Clin Nutr 1986;44:996-997.

Jurimae T, Jagomagi G, Lepp T. body composition of university students by hydrostatic weighing and skin fold measarment. J. obesity 1991;15:53-60.

Kagawa M, Kerr D, Uchida H, Binns CW. Differences in the relationship between BMI and percentage body fat between Japanese and Australian-Caucasian young men. Br J Nutr 2006;95:1002-1007.

Masaharu Kagawa, Colin W. Binns and Andrew P. Hills. Body composition and anthropometry in Japanese and Australian Caucasian males and Japanese females. Asia Pac J Clin Nutr 2007;16(1):31-36.

Norgan NG \& Ferro-Luzzi A. Weight-height indices as estimators of fatness in men. Human Nutrition 1982;36:363-372.

Ronald K Hetzler, Iris F Kimura, Karin Haines, Michelle Labotz, Joseph Smith. A Comparison of Bioelectrical Impedance and Skinfold Measurement in Determining Minimum Wrestling Weights in High School Wrestlers. Journal of Athletic Training 2006;41(1):46-51.

Ross WD, Crawford SM, Kerr DA, \& Ward R. Relationship of the body mass index with skinfolds, girths, and bone breadths in Canadian men and women aged 20-70 years. Am J Phys Anthropol 1988;77:169-173.

Schaefer F, Georgi M, Wiihl E \& Scharer K. Body mass index and percentage fat mass in healthy German schoolchildren and adolescents. Int J Obes 1998;22:461-469.

Thorburn AW. Prevalence of obesity in Australia. Obes Rev 2005;6:187-189.

\section{Information about the authors:}

Mehrzad Shabani: http://orcid.org/0000-0002-6246-3954; m.shabani@scu.ac.ir; Department of Sport Physiology, Ahvaz Shahid Chamran University; Golestan Street, 61357-43337, Ahvaz, Khuzestan, Iran.

Saeid Shakerian: http://orcid.org/0000-0002-0880-9942; sashakeryan@gmail.com; Department of Sport Physiology, Ahvaz Shahid Chamran University; 61357-43337, Ahvaz, 
Khuzestan, Iran.

Rouholah Fatemi: http://orcid.org/0000-0003-3295-4741; r.fatemi61@gmail.com; Physiology Research Center (PRC), Ahvaz Jundishapur University of Medical Sciences; Golestan Street, 61357-43337, Ahvaz, Khuzestan, Iran.

Cite this article as: Mehrzad Shabani, Saeid Shakerian, Rouholah Fatemi Study of body mass index (BMI), body fat percent $(\% \mathrm{BF})$, and waist to hip ratio (whr) in male physical education students. Physical education of students 2015;3:74-78.

http://dx.doi.org/10.15561/20755279.2015.0309

The electronic version of this article is the complete one and can be found online at: http://www.sportpedu.org.ua/html/arhive-e.html

This is an Open Access article distributed under the terms of the Creative Commons Attribution License, which permits unrestricted use, distribution, and reproduction in any medium, provided the original work is properly cited (http://creativecommons.org/licenses/by/3.0/deed.en).

Received: 18.06.2015

Accepted: 25.06.2015; Published: 30.06.2015 